\title{
REPRESENTASI MATEMATIS MAHASISWA PADA MATERI DIMENSI TIGA BERDASARKAN TEORI APOS SELAMA ONLINE LEARNING
}

\author{
Yuli Ismi Nahdiyati Ilmi \\ ${ }^{1}$ Program Studi Pendidikan Matematika, Universitas Islam Malang \\ Email: ${ }^{1}$ yuliismi.ni@unisma.ac.id
}

\begin{abstract}
ABSTRAK
Penelitian ini bertujuan untuk mendeskripsikan representasi matematis mahasiswa selama pembelajaran online pada materi dimensi berdasarkan teori APOS. Jenis penelitan ini yaitu kualitaitif deskriptif, subjek terdiri dari 3, yaitu masing-masing berkemampuan rendah, sedang, dan tinggi. Subjek merupakan mahasiswa prodi pendidikan matematika semester 2 yang telah menempuh mata kuliah telaah materi sekolah menengah 1 , khususnya pada materi dimensi tiga. Sumber data berupa hasil scan jawaban dan dianalisis melalui prosedur reduksi data, pengkategorian, dan penarikan kseimpulan. Adapun kesimpulan yang diperoleh yaitu S1 sebagai kategori subjek berkemampuan rendah, representasi kemampuan matematis yang tampak hanya pada aksi dan proses, sedangkan S2 sebagai kategori berkemampuan sedang terlihat representasi pada aksi, proses, dan objek, sedangkan S3 memenuhi tahapan pada aksi, proses, objek, dan skema.
\end{abstract}

Kata Kunci: online learning, representasi, APOS

\begin{abstract}
This study aims to describe the mathematical representation of students during online learning on dimensional material based on APOS theory. This type of research is descriptive qualitative, the subject consists of 3, namely each with low, medium, and high abilities. The subject is a student of the second semester of mathematics education study program who has taken the subject of study material for high school 1, especially in three-dimensional material. Sources of data are scanned answers and analyzed through data reduction procedures, categorization, and drawing conclusions. The conclusions obtained are that S1 as a category of low-ability subject, representation of mathematical ability that appears only in actions and processes, while $S 2$ as a category of moderate ability looks at representations of actions, processes, and objects, while S3 fulfills the stages of action, process, object, and schema.
\end{abstract}

Keywords: online learning, representation, APOS

\section{PENDAHULUAN}

Pendidikan pada masa pendemi covid-19 merupakan salah satu sektor yang paling terdampak dalam kehidupan saat ini. Pembelajaran jarak jauh menjadi pilihan utama untuk mengurangi penularan virus yang mirip dengan flu ini. Walaupun perintah protokol kesehatan agar selalu menjaga jarak minimal satu meter, menggunakan masker, dan sering cuci tangan atau menggunakan handsanitizer, penularan yang sangat cepat menambah kasus yang terdampak positif di Indonesia. Berdasarkan data dari situs UNESCO dikemukakan bahwa 577 juta pelajar di dunia terancam terkena pandemi ini.

Oleh karena itu, pembelajaran online sangat dibutuhkan untuk mendukung tetap berjalannya proses belajar mengajar. Chakraborty (2014) mengatakan bahwa pembelajaran online menciptakan pembelajaran yang menarik, adapun faktor untuk mencapai itu yaitu, menciptakan dan memelihara lingkungan belajar yang positif, 
membangun komunitas belajar, memberikan umpan balik yang konsisten secara tepat waktu, dan menggunakan teknologi yang tepat untuk mengirim konten yang tepat. Penggunaan media sangat bermanfaat sebelumnya walaupun tidak melalui pembelajaran dalam jaringan. Semakin dimasa pandemi ini pembelajaran diharuskan tanpa tatap muka, atau biasa disebut dengan tatap maya. Penggunaan zoom, google meet, Edmodo, serta aplikasi lain untuk memenuhi tujuan pembelajaran dalam pendidikan.

Matematika merupakan salah satu pelajaran yang perlu media sebagai mediasi pemahaman antara pendidik dengan pelajar. Terutama pada pembelajaran online tidak memungkiri bahwa media pembelajaran terutama berbasis android sangat diperlukan. Karena matematika tidak hanya dijelaskan melalui lisan, namun juga harus ada pergerakan, seperti dengan tulisan tangan atau media yang mendukung pemahaman pelajar. Khususnya pada bidang geometri, media sangat membantu agar pembelajaran lebih efisien, jelas, dan menarik. Seperti pada penelitian Faudiyah (2012) menyatakan bahwa siswa mengalami kesulitan dalam memahami, membayangkan atau merealisasikan bangun-bangun ruang dalam dimensi tiga. Melalui media dalam proses pembelajaran menjadi salah satu upaya mengurangi kendala siswa serta menciptakan pembelajaran yang berkualitas dan bermakna.

Dalam mengonstruksi pengetahuan, mahasiswa menggunakan cara yang berbedabeda. Hal ini memungkinkan mahasiswa mengilustrasikan berbagai macam representasi untuk dapat memahami suatu konsep ataupun untuk memecahkan permasalahan yang dihadapi. Leikin dkk (2012) dan Panasuk (2010) menyelidiki hubungan antara tingkat prestasi siswa sekolah menengah berdasarkan standar uji matematika dan kemampuan mereka untuk mengenali dan memecahkan masalah yang melibatkan "struktural yang sama" ternyata menimbulkan representasi yang berbeda. Hwang, dkk (2007) menyatakan bahwa kemampuan representasi merupakan kunci bagi siswa untuk dapat memecahkan permasalahan dengan baik. Lebih lanjut dia menjelaskan, kemampuan representasi, khususnya pada aspek text or voice representation dan aspek graph or symbol representation, memegang peranan penting dalam menggabungkan proses pembelajaran antara proses mengingat, memahami, dan mengaplikasikan.

Representasi sangat penting perannya dalam proses pembelajaran matematika seperti pada penelitian Mustangin (2020) menyebutkan representasi pada penyelesaian masalah sangat dibuthkan karena, (1) representasi sebagai standar proses yang membandingkan antara keempat standar proses yang lain, (2) representasi matematis memiliki peranan penting dalam meningkatkan permasalahan pembelajaran matematika antara pendidik dan peserta didik, serta (3) meningkatlan kualitas pemikiran ilmiah semua pihak yaitu pendidik dan peserta didik yang dapat dijadikan referensi dalam jurnal ilmiah.

Kegiatan pemodelan matematika memberikan dasar yang kokoh bagi perkembangan argumentasi anak muda karena pengalaman inheren sosial mereka (Zawojewski, Lesh, \& Inggris, 2003). Berlangsungnya pencapaian atau pembelajaran suatu konsep dan prinsip matematika, yang dapat digunakan sebagai suatu elaborasi tentang konstruksi mental terdapat aksi, proses, objek, dan skema, atau yang disingkat teori APOS (Godino, 2010). Menurut Dubinsky (2000), pemahaman terhadap suatu konsep matematika merupakan hasil konstruksi atau rekonstruksi terhadap objek-objek matematika. Konstruksi atau rekonstruksi itu dilakukan melalui aktivitas aksi-aksi, prosesproses, dan objek-objek matematika yang diorganisasikan dalam suatu skema untuk memecahkan masalah matematika.

Konsep aksi dapat menjadi konsep proses melalui konstruksi mental yang disebut pembatinan. Kemudian, siswa dapat berpikir tentang hasil dari proses tanpa benar-benar memiliki melakukannya dan, khususnya, bisa membayangkan membalikkan proses. Seorang siswa yang memiliki konsep obyek ide matematika bisa membayangkan itu 
sebagai totalitas dan, khususnya, dapat bertindak di atasnya dengan tingkat yang lebih tinggi tindakan atau proses. Proses dapat dikemas menjadi objek, dan kadang-kadang berguna bahwa siswa dapat merangkum objek untuk fokus pada proses yang mendasari. Skema dikoordinasikan koleksi tindakan, proses, objek, dan skema lainnya, yang dapat diri mereka dikemas menjadi objek.

Teori APOS muncul dari upaya untuk memahami mekanisme abstraksi reflektif, diperkenalkan oleh Piaget untuk menggambarkan perkembangan pemikiran logis pada anak-anak, dan memperluas ide ini untuk meningkatkan konsep matematika yang telah dipelajari. Dalam penelitian Baker (2000) menggunakan teori APOS untuk menganalisis skema subjekmya dalam mempelajari konsep kalkulus. Selain itu, Zazkis \& Campbell (1996) menyatakan bahwa kerangka teori APOS telah digunakan untuk menganalisis perkembangan berpikir mahasiswa dalam mempelajari topik fungsi dan grup, serta topiktopik matematika diskrit.

\section{METODE}

Penelitian ini merupakan penelitian dengan pendekatan kualitatif karena peneliti ingin memperoleh data yang mendalam dan detail secara alami, yaitu mengenai representasi matematis siswa dalam menyelesaikan kuis dimensi tiga berdasarkan teori APOS. Soal kuis ini dapat dikerjakan setelah subjek mengamati media pembelajaran berbantuan android yang dapat diunduh melalui https://play.google.com/store/apps/details?id=feri.com.mathquizz. Dikarenakan jenis penelitian ini deskriptif, walaupun subjek mengerjakan kuis dalam bentuk pilihan ganda, peneliti meminta hasil scan jawaban tersebut melalui whatsapp. Subjek penelitian ini terdiri dari 28 mahasiswa prodi pendidikan matematika yang telah menempuh mata kuliah telaah materi sekolah menengah 1 dengan materi dimensi tiga. Namun berdasarkan pengkatagorian kemampuan matematis yang telah didapat pada semester sebelumnya, serta dengan melihat hasil representasi matematis penyelesaian, subjek dipilih kembali menjadi 3, yaitu kemampuan rendah, sedang, dan berkemampuan tinggi. Soal yang diberikan terdiri dari 5 soal, namun fokus pemilihan soal dalam melihat rekonstruksi teori APOS hanya satu soal saja yang dapat terlihat berdasarkan penyelesaian subjek. Sumber data yang digunakan dalam penelitian ini yaitu berupa hasil scan jawaban subjek yang telah terpilih dengan karakteristik yang berbeda dan unik.

Karakteristik unik diartikan dengan cara penyelesaian subjek yang berbeda dan tidak pada umumnya, namun tetap dapat terlihat bagian-bagian aksi, proses, objek, dan skema. Analisis data pada penelitian ini mengacu berdasarkan Miles dan Huberman (Sugiyono, 2012:247-252) yaitu meliputi (1) reduksi data, (2) pemaparan data/kategorisasi, (3) penarikan kesimpulan. Reduksi data adalah proses pemilihan, pemusatan perhatian pada penyederhanaan, pengabstrakan, dan transformasi data "kasar" di lapangan. Reduksi data yang dilakukan dalam penelitian ini, yaitu kegiatan yang mengacu pada proses pemilihan dan pengidentifikasian data yang memiliki makna jika dikaitkan dengan pertanyaan penelitian, dan selanjutnya membuat koding pada setiap satuan sehingga diketahui berasal dari sumber mana. Dalam penelitian ini, petunjuk pengkodingan yang digunakan dalam mendeskripsikan hasil penelitian yang berbentuk representasi matematis siswa berdasarkan teori APOS dalam menyelesaikan soal yang berkaitan dengan dimensi tiga. Penyajian data meliputi pengklasifikasian dan identifikasi data, yaitu menuliskan kumpulan data yang terorganisasi dan terkategori sehingga memungkinkan untuk menarik kesimpulan dari data tersebut. Kategorisasi dimaksudkan untuk: (1) mengelompokkan bagian-bagian data yang berkaitan, (2) merumuskan aturan yang menguraikan kawasan kategori dan akhirnya dapat digunakan untuk menetapkan inklusi kategori dan juga sebagai dasar pemeriksaan keabsahan data, dan (3) menjaga agar 
setiap kategori yang telah disusun satu dengan yang lainnya mengikuti prinsip langkah yang telah ditentukan.

Coding merupakan proses mengolah materi atau informasi menjadi segmensegmen tulisan sebelum memaknainya. Langkah ini melibatkan beberapa tahap yaitu mengambil data tulisan yang telah dikumpulkan, mensegmentasi kalimat-kalimat ke dalam kategori-kategori, kemudian melabeli kategori-kategori tersebut dengan istilah khusus. Deskripsi dari representasi dimensi tiga yang berdasarkan teori APOS dituliskan dalam bentuk narasi secara sistematis, objektif dan sesuai dengan keadaan yang sebenarnya. Data yang telah ditulis dalam bentuk narasi dimaknai dalam suatu kesimpulan. Kesimpulan dibuat dengan mengaitkan antara representasi matematis siswa dalam menyelesaikan soal dimensi tiga berdasarkan teori APOS.

\section{HASIL}

Berdasarkan analisis data, diperoleh yaitu dari reduksi data, semula subjek penelitian yang terdiri dari 28 mahasiswa, karena disesuaikan dengan data yang diinginkan dan sesuai dengan representasi berdasarkan teori APOS, maka direduksi menjadi sebanyak 3 subjek, yaitu masing-masing berkemampuan tinggi, sedang, dan rendah. Kemudian hasil analisis berikutnya pada pemaparan data diperoleh, representasi matematis pada ketiga subjek pada aksi, proses, objek, dan skema. Representasi aksi tercapai ketika subjek memahami penyelesaian soal dimensi tiga melalui gambar atau bentuk bagun dimensi tiga, namun penentuan cara yang digunakan masih bisa jadi belum tepat. Representasi proses dihasilkan melalui penguatan repesentasi berbentuk kata atau tulisan untuk menjelaskan gambar yang telah diperoleh pada tahap aksi. Representasi objek tercapai ketika subjek memilih cara penyelesaian dengan menghubungkan permasalahan dari gambar, namun masih belum menggunakan cara yang tepat. Representasi skema dihasilkan ketika subjek dapat merepresentasi penyelesaian dari permasalahan dimensi tiga dengan lengkap dan dapat menghubungkan secara detail permaslahan dimensi tiga melalui gambar dan tulisan.

Namun, cara dari ketiga subjek membedakan alur tahapan yang dicapai. Yaitu pada S1 dengan kategori rendah menjawab soal tanpa mengetahui tujuan alur yang dikerjakan, yaitu seperti pada gambar berikut.

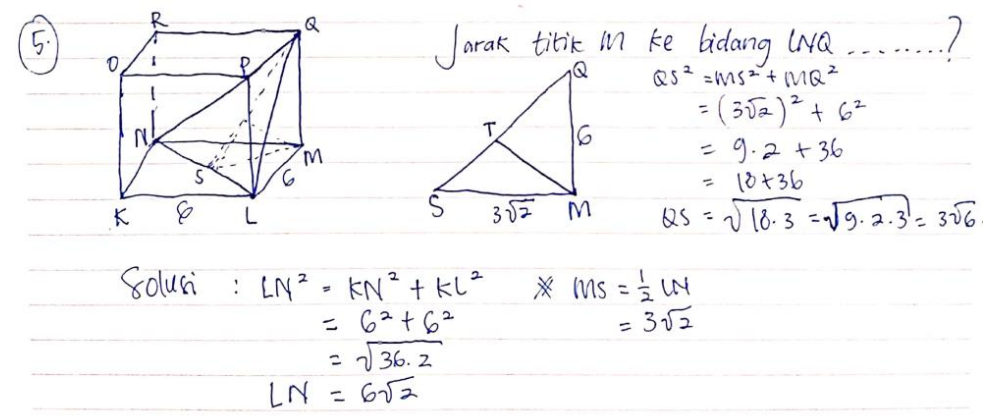

Gambar 1. Representasi Matematis S1

Berdasarkan gambar diatas diperoleh representasi aksi tercapai ketika S1menyelesaikan dengan langsung mencari panjang QS melalui phytagoras, hal ini S1 mentransformasikan penyelesaian soal tanpa memahami tujuan dari langkah-langkah yang dikerjakan. Terlihat dari gambar, bahwa representasi matematis ketika mencari panjang QS tidak digunakan kembali pada pencarian panjang LN atau MS. Apabila aksi dilakukan berulang-ulang dan dilakukan refleksi atas aksi itu, maka aksi-aksi itu diinteriosisasikan menjadi suatu proses, terlihat proses pada S1 ini masih kurang begitu lengkap dikarenakan alur penyelesaian pada dimensi tiga masih tidak begitu jelas. Dikarenakan pada representasi proses masih belum tepat, sehingga untuk representasi objek dan skema belum tampak 
Pemaparan pada S2 kategori sedang, yaitu dapat terlihat dari representasi penyelesaian hanya sampai pada tahap objek, yaitu pada gambar berikut.

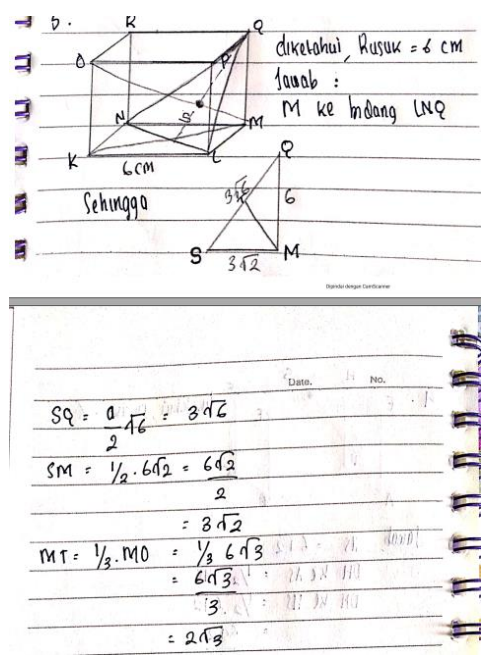

Gambar 2. Representasi Matematis S2

Berdasarkan penyelesaian dari S2, representasi aksi terlihat yaitu berupa gambar dimensi tiga serta simbolik dari penyelesaian pada tiap tahapnya. Kemudian pada representasi proses terlihat jelas pada penyelesaian bahwa S2 memahami tujuan dari apa yang ditanyakan pada soal. Namun, pada representasi objek juga terlihat tetapi masih belum bisa dijelaskan dari gambar yaitu poin $\mathrm{S}$ dan poin $\mathrm{T}$, sehingga meragukan juga panjang dari SQ yaitu langsung setengah panjang rusuk akar 6 yaitu menghasilkan tiga akar enam. Kemudian untuk mencari MT langsung sepertiga dari panjang MO. Sehingga representasi skema pada penyelesaian S3 belum tercapai, dikarenakan belum dapat mengaitkan antara aksi dan proses untuk menggunakan objek matematika tertentu.

Kemudian pada pemaparan S3 kategori tinggi, terlihat lengkap antara aksi, proses, objek, dan skema. Adapun representasi penyelesaian dari S3 yaitu sebagai berikut.

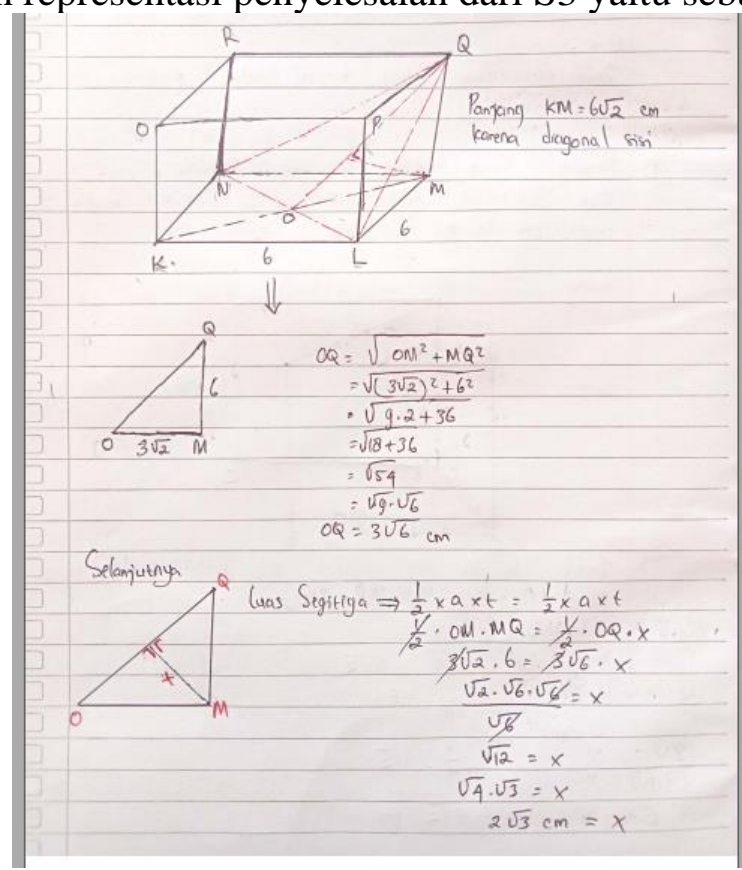

Gambar 3. Representasi Matematis S3

Pada penyelesaian diatas, terlihat bahwa representasi aksi pada S3 yaitu berupa gambar dimensi tiga serta simbolik yang berupa penyelesaian soal. Terbentuknya representasi proses nampak ketika mencari jarak dengan menggunakan pendekatan luas segitiga. Hal ini dapat dikatakan bahwa representasi skema S3 yaitu menggunakan aksi, 
proses, objek untuk membetuk objek baru yaitu mencari jarak antara titik dan bidang dalam dimensi tiga.

Dari ketiga subjek dapat disimpulkan bahwa S1 menjawab salah, S2 menjawab benar, namun prosedur yang digunakan masih meragukan, kemudian S3 menjawab dengan benar serta mengaitkan luas segitiga dalam mencari jarak antara titik dan bidang. Representasi aksi tampak pada S1, S2, dan S3 yaitu berupa gambar dimensi tiga serta simbolik penyelesaian. Kemudian representasi proses hanya terlihat pada S2 dan S3 yaitu ketika menjawab sudah sesuai dengan alur penyelesaian, sedangkan representasi objek juga tampak pada S2 dan S3 yaitu berupa penerapan dari aksi dan proses, yaitu dapat menyelesaikan soal dengan tepat. Berbeda dengan S3, S4 juga menjawab dengan tepat dan secara jelas alur penyelesaian dengan mengaitkan aksi, proses, objek, untuk mebentuk objek baru atau disebut tematisasi.

\section{PEMBAHASAN}

Berdasarkan pemaparan diatas sesuai dengan penelitian oleh Astuti (2017) yang menyatakan bahwa subjek dengan nilai akademik sedang dan tinggi dapat mereprsentasikan penyelesaian masalah matematika dengan baik, sedangkan subjek dengan nilai akademik rendah, belum dapat merepresentasikan dengan baik ataupun lengkap.

Representasi penyelesaian subjek pada soal dimensi tiga dengan berdasarkan teori APOS berada tahap aksi, jika subjek hanya mampu menyelesaikan soal tanpa memahami konsep dari dimensi tiga. Seperti pada soal nomor 5 dilakukan dengan aktivitas prosedural yaitu menentukan jarak antara titik $M$ pada bidang LNQ. Hal tersebut sesuai dengan pendapat Dubinsky (2000) yang menyatakan, jika aksi merupkan aktivitas berupa pengulangan fisik atau manipulasi mental dengan mentransformasikan objek matematika melalui beberapa cara, atau aktivitas yang mendasarkan pada beberapa algoritma secara eksplisit.

Representasi pada proses dapat diketahui setelah subjek dapat menjelaskan cara yang digunakan, pada penelitian ini terlihat terdapat perubahan semula subjek yang mencapai pada tahap aksi, berubah menjadi tahap proses. Hal ini sesuai dengan pendapat Adu-Gyamfi dan Michael (2013) yang menjelaskan bahwa siswa dalam memahami konsep matematika dapat terlihat melalui representasi yang disampaikannya, namun ketika siswa dalam mengomunikasikan konseptual menghasilkan representasi yang berbeda.

Representasi objek akan nampak terlihat ketika subjek mampu menjawab dengan benar persoalan yang diberikan. Hal tersebut sesuai dengan Goldin, dkk (2008) yang menyebutkan representasi eksternal mengacu pada perwujudan konfigurasi fisik yang diamati seperti kata-kata, grafik, gambar, persamaan, dan tabel.

Pada tahap skema, subjek dapat mengkoordinasikan aksi, proses, dan objek untuk membentuk suatu skema awal tentang dimensi tiga. Kondisi tersebut dapat dikatakan S3 telah mentematisasikan suatu objek ke skema, menurut Dubinsky (2000) tematisasi merupakan konstruksi yang mengaitkan aksi, proses, dan objek yang terpisah untuk suatu objek tertentu sehingga menghasilkan suatu skema.

\section{SIMPULAN DAN SARAN}

Berdasarkan pemaparan diatas dapat disimpulkan bahwa S1 sebagai kategori subjek berkemampuan rendah, representasi yang tampak hanya pada aksi dan proses, sedangkan S2 sebagai kategori berkemampuan sedang terlihat representasi pada aksi, proses, dan objek, sedangkan S3 memenuhi representasi aksi, proses, objek, dan skema.

Saran berdasarkan penelitian ini perlu adanya perbandingan antara rekontruksi pemahaman dalam bidang aljabar dan geometri. Karena berdasarkan representasi aksi, proses, objek dan skema pada semua subjek dalam bidang geometri tampak terlihat 
prosedural, sedangkan dalam hal aljabar ada kemungkinan reprsentasi yang dihasilkan lebih variatif.

\section{DAFTAR RUJUKAN}

Adu-Gyamfi, Kwaku dan Michael J. Bosse. (2013). Processes and Reasoning in Representations of Linear Functions. International Journal of Science \& Mathematics Education. Feb, Vol. 12 Issue 1, p167-192. 26p.

Astuti, Erni Puji. (2017). Representasi Matematis Mahasiswa Calon Guru dalam Menyelesaikan Masalah Matematika. Beta Jurnal Tadris Matematika. vol.10 No. 1, hal 70-82

Baker, B., Cooley, L., dan Trigueros, M. (2000). A Calculus Graphing Schema. Journal For Research in Mathematics Education. 31(5): 557-578.

Chakraborty, M. and Muyia Nafukho, F. (2014). "Strengthening student engagement: what do students want in online courses?". European Journal of Training and Development. Vol.38, No. 9, pp. 782-802.

Dubinsky, Ed \& Mc Donald, M.A. (2000). APOS: A Constructivist Theory of Learning in Undergraduate. Mathematics Education Research. (Online)

Godino, Juan D. (2010). The theory of representations as viewed from the onto-semiotic approach to mathematics education. Research in Mathematics Education . Vol. 9, 1, $189-210$

Goldin. G. (2008). Perspectives on representation in mathematical learning and problem solving. In L. D. English (Ed.) Handbook of International Research in Mathematics Education (176- 201).

Hwang, W. Y., Chen, N. S., Dung, J. J., \& Yang, Y. L. (2007). Multiple Representation Skills and Creativity Effects on Mathematical Problem Solving using a Multimedia Whiteboard System. Educational Technology \& Society. Vol 10 No 2, pp. 191-212.

Leikin, Roza dkk. (2012). Effect of the presence of external representations On accuracy and reaction time in solving Mathematical double-choice problems by students of different levels of instruction. International Journal of Science \& Mathematics Education. 11: 1049Y1066

Panasuk, R. dan Beyranevand, M. (2010). Algebra Students' Ability to Recognize Multiple Representations and Achievement. International Journal for Mathematics Teaching and Learning. Available di http://www.cimt.plymouth.ac.uk/journal/panasuk.pdf

Sugiyono. (2012). Memahami Penelitian Kualitatif. Bandung: ALFABETA 